\title{
Schizosaccharomyces pombe Polysome Profile Analysis and RNA Purification
}

\author{
Dieter A. Wolf,1,4 Jürg Bähler, ${ }^{2,4}$ and Jo Ann Wise ${ }^{3}$ \\ ${ }^{1}$ Degenerative Disease Program, Sanford Burnham Prebys Medical Discovery Institute, La Jolla, California 92037; \\ ${ }^{2}$ Department of Genetics, Evolution \& Environment, and UCL Cancer Institute, University College London, \\ London WC1E 6BT, United Kingdom; ${ }^{3}$ Center for RNA Molecular Biology and Department of Biochemistry, \\ Case Western Reserve University, Cleveland, Ohio 44106-4906
}

\section{MATERIALS}

Polysome profile analysis is widely used by investigators studying the mechanism and regulation of translation. The method described here uses high-velocity centrifugation of whole cell extracts on linear sucrose gradients to separate $40 \mathrm{~S}$ and $60 \mathrm{~S}$ ribosomal subunits from $80 \mathrm{~S}$ monosomes and polysomes. Cycloheximide is included in the lysis buffer to "freeze" polysomes by blocking translation. After centrifugation, the gradient is fractionated and RNA (and/or protein) is prepared from each fraction for subsequent analysis of individual species using northern or western blots. The entire RNA population in each fraction can be analyzed by hybridization to microarrays or by high-throughput RNA sequencing, and the proteins present can be identified by mass spectrometry analysis.

It is essential that you consult the appropriate Material Safety Data Sheets and your institution's Environmental Health and Safety Office for proper handling of equipment and hazardous material used in this protocol.

RECIPES: Please see the end of this protocol for recipes indicated by $<R>$. Additional recipes can be found online at http://cshprotocols.cshlp.org/site/recipes.

Reagents

Cycloheximide (100 mg/mL in $\mathrm{H}_{2} \mathrm{O}$ ) (optional; see Step 1)

Ethanol (85\% [v/v] in water) (optional; see Step 18$)$

Ethanol (100\%)

Ethylenediaminetetraacetic acid (EDTA) (500 mm) (optional; see Step 4.ii)

Guanidinium hydrochloride ( $8 \mathrm{~m}$ in double-distilled $\mathrm{H}_{2} \mathrm{O}$ ) (optional; see Step 16.iv)

Isopropanol

Polyribosomal lysis buffer $<\mathrm{R}>$ (for nonpuromycin-treated isolation procedures)

Polyribosomal lysis buffer with puromycin $<\mathrm{R}>$ (for puromycin-treated isolation procedures only)

Puromycin dihydrochloride (1 mM) (optional; see Step 4.i)

Puromycin is a tRNA mimic that causes polypeptide chain termination.

${ }^{4}$ Correspondence: dwolf@sbpdiscovery.org; j.bahler@ucl.ac.uk

From the Fission Yeast collection, edited by lain M. Hagan, Antony M. Carr, Agnes Grallert, and Paul Nurse.

(c) 2017 Cold Spring Harbor Laboratory Press

Cite this protocol as Cold Spring Harb Protoc; doi:10.1101/pdb.prot091637 
D.A. Wolf et al.

RNase I (Ambion) (optional; see Step 4.vi)

RNase A (optional; see Step 4.iv)

RNase T1 (Ambion) (optional; see Step 4.iv)

RNeasy kit (QIAGEN)

S. pombe cells $\left(0.5-1.0 \times 10^{7}\right.$ cells $\left./ \mathrm{mL}\right)$

Sucrose gradient solutions $(10 \%, 50 \%$, and $55 \%[\mathrm{w} / \mathrm{v}]$, prepared in polyribosomal lysis buffer)

Water, RNase-free

\section{Equipment}

Beads, zirconia (0.5 mm diameter) (Biospec; Sigma-Aldrich)

Centrifuge, benchtop, equipped with swing-out rotor for 50-mL tubes

FastPrep device (MP Biomedicals)

Gradient fractionator (Brendel or ISCO)

Gradient maker (e.g., Biocomp or Sigma-Aldrich)

Microcentrifuge

Microcentrifuge tubes (flip-top, $1.5-\mathrm{mL}$ )

Microcentrifuge tubes (screw-cap, 1.5-mL)

Microscope, phase contrast/bright field, equipped with $40 \times$ objective and $10 \times$ eyepieces

Needle (18-gauge)

Spectrophotometer (NanoDrop)

Tubes, glass (to fit the fraction collector)

Tubes (screw-cap, 50-mL) (Beckman)

Tubes, ultracentrifuge, polyallomer

Ultracentrifuge (e.g., Beckman Optima X), equipped with Sw40Ti or Sw41Ti rotors

1. Harvest $0.3-0.7 \times 10^{9}$ mid-log phase cells by pouring the culture directly into $50-\mathrm{mL}$ screw-cap centrifuge tubes on ice containing cycloheximide at a final concentration of $100 \mu \mathrm{g} / \mathrm{mL}$. Centrifuge for $4-5 \mathrm{~min}$ at $670-1000 \mathrm{~g}$ or $3 \mathrm{~min}$ at $2000 \mathrm{~g}$. Discard the culture fluid by decanting carefully.

Alternatively, add cycloheximide to the culture 5 min before harvesting to allow time for the inhibitor to work. In this case, pellet cells by centrifugation immediately (i.e., without additional added cycloheximide).

For studies in which polysome disruption involves treatment with puromycin (see Step 4.i), omit the cycloheximide treatment from Step 1, and use polyribosomal lysis buffer with puromycin throughout the protocol in place of the standard polyribosomal lysis buffer.

2. Wash cells with $0.9 \mathrm{~mL}$ of polyribosomal lysis buffer to remove residual media. Resuspend the pellet in $200 \mu \mathrm{L}$ of ice-cold polyribosomal lysis buffer.

3. Transfer the cell suspension to prechilled $1.5-\mathrm{mL}$ screw-cap microcentrifuge tube containing $\sim 600 \mu \mathrm{L}$ of zirconia beads. Lyse in a FastPrep device at level 6.0 for $18 \mathrm{sec}$ (shorter times down to $13 \mathrm{sec}$ can also be used).

Check an aliquot of the suspension using a microscope to ensure that at least $50 \%-70 \%$ of the cells have been lysed. If $>30 \%-50 \%$ cells remain intact, repeat the FastPrep step.

4. (Optional) Disrupt polysomes as necessary using one of the following methods:

\section{To induce polypeptide chain termination}

i. Treat lysate with $1 \mathrm{~mm}$ puromycin for $15 \mathrm{~min}$.

Alternatively, add $1 \mathrm{~mm}$ puromycin to the cells for 1-10 min before disruption. 


\section{To dissociate ribosomal subunits}

ii. Add $25 \mu \mathrm{L}$ of the $500 \mathrm{~mm}$ EDTA stock solution to $500 \mu \mathrm{L}$ cell lysate, that is, to a final concentration of $25 \mathrm{~mm}$.

iii. Incubate for $15 \mathrm{~min}$ at room temperature.

\section{To cleave RNA between individual ribosomes (Method 1)}

iv. Add RNase A and RNase T1 to final concentrations of 25 and $1000 \mathrm{U} / \mathrm{mL}$, respectively, to the cell lysate.

v. Incubate for $15 \mathrm{~min}$ at room temperature.

\section{To cleave RNA between individual ribosomes (Method 2)}

The efficacy of this procedure can vary with the batch of RNase and/or strain of yeast under investigation.

vi. Add $750 \mathrm{U}$ of RNase I to a cell lysate suspension with an $\mathrm{OD}_{260}$ of 40 units.

vii. Incubate for $30 \mathrm{~min}$ at room temperature.

5. After lysis (and any subsequent dissociative treatments), poke a hole in the bottom of the screwcap microcentrifuge tube using an 18-gauge needle.

6. Insert the perforated tube inside a $1.5-\mathrm{mL}$ flip-top microcentrifuge tube. Separate the liquid from the beads in the upper tube by centrifugation at $5000 \mathrm{~g}$ for $5 \mathrm{~min}$ at $4^{\circ} \mathrm{C}$. Reserve the liquid collected in the flip-top tube.

7. Add $250-350 \mu \mathrm{L}$ of polyribosomal lysis buffer to the beads in the perforated tube. Repeat Step 6. Combine the flowthroughs from Steps 6 to 7.

8. Clear the lysate by centrifugation at $20,000 \mathrm{~g}$ for $15 \mathrm{~min}$ at $4^{\circ} \mathrm{C}$.

9. Add $2 \mu \mathrm{L}$ of the lysate to $98 \mu \mathrm{L}$ of $\mathrm{dH}_{2} \mathrm{O}$. Measure the $\mathrm{OD}_{260}$ of the diluted solution in a NanoDrop spectrophotometer.

10. Prepare 11-mL linear (10\%-50\%) sucrose gradients.

Sucrose gradients can be stored in a cold room for up to $4 \mathrm{~h}$ at $4^{\circ} \mathrm{C}$, with or without lysate layered on top. Do not store in a refrigerator; vibrations from the motor can disturb the gradient. See Pospísek and Valásek (2013) for details on gradient separation.

11. Dilute aliquots corresponding to $20-25 \mathrm{OD}_{260}$ units to $350 \mu \mathrm{L}$ with lysis buffer (with or without the protease inhibitor cocktail, heparin and RNasin). Layer onto the sucrose gradients.

When comparing polysome profiles from different cells, it is important to load the same number of $O D$ units.

12. Centrifuge the sucrose gradients at $4^{\circ} \mathrm{C}$ in a Beckman SW40Ti rotor at $39,000 \mathrm{rpm}(\sim 277,000 \mathrm{~g})$ for 150 min or a Beckman SW41Ti rotor at 35,000 rpm ( 246,000g) for $160 \mathrm{~min}$.

It is important to precool the centrifuge and all rotor parts.

13. Remove gradients carefully to avoid disturbing the separation.

14. Prewash the tubing through which the fractionated samples will pass with ethanol, then with water, and finally with sucrose solution.

15. Fractionate each tube by upward displacement with $55 \%$ sucrose using a gradient fractionator:

The precise manipulations will vary depending on the exact combination of fractionator, UV monitor, and fraction collector. Some fractionators require a warming-up period.

\section{Using a Brendel fractionator}

i. Set the flow rate at $800 \mu \mathrm{L} / \mathrm{min}$.

\section{Using an ISCO fractionator}

ii. Use a pump speed of $50 \%, 10 \times(\sim 1.25 \mathrm{~mL} / \mathrm{min})$. 
D.A. Wolf et al.

16. From each gradient, collect $12-13$ fractions of $800-900 \mu \mathrm{L}$ each:

\section{For protein isolation}

i. Collect fractions into empty glass tubes.

\section{For RNA isolation (Method 1)}

ii. Collect fractions into tubes prefilled with $1.9-2.1 \mathrm{~mL} \mathrm{100 \%} \mathrm{isopropanol.}$ The final isopropanol concentration should be $\sim 70 \%$.

iii. Mix each sample with the isopropanol. Precipitate overnight at $-20^{\circ} \mathrm{C}$.

\section{For RNA isolation (Method 2)}

iv. Collect fractions into tubes prefilled with $2 \mathrm{~mL}$ of $8 \mathrm{~m}$ guanidinium hydrochloride. The final concentration after collection should be $5.5 \mathrm{M}$.

v. Add 1 volume of $100 \%$ ethanol. Mix by inversion. Precipitate overnight at $-20^{\circ} \mathrm{C}$.

17. After RNA precipitation (i.e., Step 16.iii or Step 16.v), centrifuge samples for $20 \mathrm{~min}$ at $>10,000 \mathrm{~g}$ at $4^{\circ} \mathrm{C}$. Discard the supernatant.

Alternatively, centrifuge at $3000 \mathrm{~g}$ for $90 \mathrm{~min}$.

18. (Optional) Wash pellets with $1 \mathrm{~mL}$ of $85 \%$ ethanol (see Protocol: Preparation of Total RNA from Fission Yeast [Bähler and Wise 2016] for tips to avoid losing the pellet).

19. Air-dry the RNA pellets for $20 \mathrm{~min}$. Resuspend in $100 \mu \mathrm{L}$ of RNase-free water.

20. Purify RNA using a QIAGEN RNeasy kit according to the manufacturer's instructions.

\section{RELATED INFORMATION}

For additional information on the use of polysome profile analysis to study the mechanisms and regulation of translation, see Rallis et al. (2014). Procedures for RNA analysis by microarray hybridization are described in Lackner et al. (2012).

\section{RECIPES}

Polysomal Lysis Buffer

Tris- $\mathrm{HCl}(\mathrm{pH} 7.5)$

$\mathrm{KCl}$

$\mathrm{MgCl}_{2}$

Cycloheximide

Dithiothreitol (DTT)

cOmplete protease inhibitor cocktail

tablets, EDTA-free (Roche)

Heparin

RNasin (Promega)

Phenylmethylsulfonyl fluoride (PMSF)
$20 \mathrm{~mm}$

$50 \mathrm{~mm}$

$10 \mathrm{~mm}$

$100 \mu \mathrm{g} / \mathrm{mL}$

$1 \mathrm{~mm}$

2 tablets/100 mL culture

$0.2 \mathrm{mg} / \mathrm{mL}$

$1 \mu \mathrm{L} / \mathrm{mL}$

$1 \mathrm{~mm}$

Combine the first three ingredients. (If desired, a $10 \times$ stock solution containing $200 \mathrm{~mm}$ Tris- $\mathrm{HCl}, 500 \mathrm{~mm} \mathrm{KCl}$, and $100 \mathrm{~mm} \mathrm{MgCl}_{2}$ can be prepared and stored on a long-term basis.) Just before use, add the cycloheximide and DTT, as well as the protease inhibitor tablets, heparin, and RNasin (the latter three are optional but highly recommended). For processing meiotic cells, include PMSF. 
Polysomal Lysis Buffer with Puromycin

Tris- $\mathrm{HCl}(\mathrm{pH} 7.5)$

$\mathrm{KCl}$

$\mathrm{MgCl}_{2}$

Puromycin

Dithiothreitol (DTT)

cOmplete protease inhibitor cocktail

tablets, EDTA-free (Roche)

Heparin

RNasin (Promega)

Phenylmethylsulfonyl fluoride (PMSF)

\author{
$20 \mathrm{~mm}$ \\ $500 \mathrm{~mm}$ \\ $2 \mathrm{mM}$ \\ $1 \mathrm{mM}$
}

Combine the first three ingredients. Just before use, add the puromycin and DTT, as well as the protease inhibitor tablets, heparin, and RNasin (the latter three are optional but highly recommended). For processing meiotic cells, include PMSF.

\title{
ACKNOWLEDGMENTS
}

D.A.W. was supported by the National Institutes of Health USA, J.B. was supported by the Wellcome Trust UK, and J.A.W. was supported by the National Science Foundation USA. This protocol is an amalgamation of procedures followed in the laboratories of Dieter Wolf and Jürg Bähler. The authors thank Charalampos Rallis (University College London, UK) for helpful comments.

\section{REFERENCES}

Bähler J, Wise JA. 2016. Preparation of total RNA from fission yeast. Cold Spring Harb Protoc doi: 10.1101/pdb.prot091629.

Lackner DH, Schmidt MW, Wu S, Wolf DA, Bähler J. 2012. Regulation of transcriptome, translation, and proteome in response to environmental stress in fission yeast. Genome Biol 13: R25.
Pospísek M, Valásek L. 2013. Polysome profile analysis—Yeast. Methods Enzymol 530: 173-181.

Rallis C, López-Maury L, Georgescu T, Pancaldi V, Bähler J. 2014. Systematic screen for mutants resistant to TORC1 inhibition in fission yeast reveals genes involved in cellular ageing and growth. Biol Open 3: 161-171. 


\section{Schizosaccharomyces pombe Polysome Profile Analysis and RNA Purification}

Dieter A. Wolf, Jürg Bähler and Jo Ann Wise

Cold Spring Harb Protoc; doi: 10.1101/pdb.prot091637

\begin{tabular}{rc}
$\begin{array}{r}\text { Email Alerting } \\
\text { Service }\end{array}$ & Receive free email alerts when new articles cite this article - click here. \\
\hline Subject & Browse articles on similar topics from Cold Spring Harbor Protocols. \\
Categories & Analysis of Protein Expression in Cultured Cells (44 articles) \\
& mRNA (111 articles) \\
& Preparation of Cellular and Subcellular Extracts (90 articles) \\
& RNA (251 articles) \\
& RNA Purification (56 articles) \\
& Subcellular Fractionation (70 articles) \\
& Yeast (219 articles) \\
\hline
\end{tabular}

